\title{
Molecular detection of Cercopithifilaria bainae and other tick-borne pathogens in Rhipicephalus sanguineus s.l. isolated from dogs in Midwest Brazil
}

\author{
Detecção molecular de Cercopithifilaria bainae e outros patógenos \\ transmitidos por carrapatos em Rhipicephalus sanguineus s.l. isolados \\ de cães no Centro-Oeste do Brasil \\ Rodrigo Leite Soares ${ }^{1 *}$ (D), Angélica Oliveira da Silva', Mateus Lotério Coelho, \\ Jessica Teles Echeverria ${ }^{1}$, Michelli Lopes de Souza ${ }^{1}$, Veronica Jorge Babo-Terra ${ }^{1}$, \\ Taynara Nunes Pasquatti², Rafael Antonio Nascimento Ramos ${ }^{3}$, \\ Carlos Alberto do Nascimento Ramos ${ }^{1}$ \\ ${ }^{1}$ Faculdade de Medicina Veterinária e Zootecnia (FAMEZ), Universidade Federal de Mato Grosso do Sul (UFMS), Campo \\ Grande, MS, Brasil \\ 2 Universidade Católica Dom Bosco, Campo Grande, MS, Brasil \\ ${ }^{3}$ Unidade Acadêmica de Garanhuns, Universidade Federal Rural de Pernambuco (UFPRE), Garanhuns, PE, Brasil
}

How to cite: Soares RL, Silva AO, Coelho ML, Echeverria JT, Souza ML, Babo-Terra VJ, Pasquatti TN, Ramos RAN, Ramos CAN. Molecular detection of Cercopithifilaria bainae and other tick-borne pathogens in Rhipicephalus sanguineus s.l. isolated from dogs in Midwest Brazil. Braz J Vet Parasitol 2020; 29(1): e018019.

https://doi.org/10.1590/S1984-29612019109

\begin{abstract}
The aim of the present study was to detect Cercopithifilaria bainae and other tick-borne pathogens and to perform molecular characterization of the tick Rhipicephalus sanguineus s.l. collected from dogs. Ticks ( $n=432$, including 8 larvae, 59 nymphs, and 365 adults) were sampled from domiciled dogs ( $n=73$ ) living in Campo Grande, Mato Grosso do Sul (Midwest Brazil). All ticks were morphologically identified as $R$. sanguineus. Genomic DNA was extracted in pools (three to five ticks per animal) and was used for definition of $R$. sanguineus haplotypes (based on 16S rRNA analysis) and pathogen identification (Cercopithifilaria sp., Ehrlichia canis, Anaplasma platys, Hepatozoon canis, Babesia vogeli and Rickettsia spp.). Rhipicephal us sanguineus specimens were identified as haplotypes A and B. DNA of Cercopithifilaria bainae (43.83\%; 32/73), Ehrlichia canis (24.65\%; 18/73), Anaplasma platys (19.17\%; 14/73), and Hepatozoon canis (5.47\%; 4/73) was detected. The identity of pathogens was confirmed by DNA sequence analysis. The present study confirms the presence of haplotypes $A$ and $\mathrm{B}$ of $R$. sanguineus in the state of Mato Grosso do Sul and its importance as a vector of several pathogens of veterinary concern. Finally, this is the first report to identify $C$. bainae in ticks in the Midwestern region of Brazil.
\end{abstract}

Keywords: Ticks, genetic characterization, dog, central western region, Brazil.

\section{Resumo}

O objetivo do presente estudo foi detectar Cercopithifilaria bainae e outros patógenos transmitidos por carrapatos e realizar a caracterização molecular do carrapato Rhipicephalus sanguineus s.l. coletado em cães. Carrapatos ( $n=432$, incluindo 8 larvas, 59 ninfas e 365 adultos) foram amostrados de cães domiciliados $(n=73)$ residentes no município de Campo Grande, Mato Grosso do Sul (centro-oeste do Brasil). Todos os carrapatos foram identificados morfologicamente como $R$. sanguineus. O DNA genômico foi extraído em pools (três a cinco carrapatos por animal), seguido pela definição de haplótipos (com base no gene 16S rRNA) e pela investigação de patógenos 
(Cercopithifilaria sp., Ehrlichia canis, Anaplasma platys, Hepatozoon canis, Babesia vogeli e Rickettsia spp.). Os espécimes coletados foram identificados como haplótipos $\mathrm{A}$ e $\mathrm{B}$ de $R$. sanguineus. Foram detectados DNA de Cercopithifilaria bainae (43,83\%; 32/73), Ehrlichia canis (24,65\%; 18/73), Anaplasma platys $(19,17 \% ; 14 / 73)$ e Hepatozoon canis $(5,47 \% ; 4 / 73)$. A identidade dos patógenos foi confirmada por análise de sequência de DNA. O presente estudo confirma a circulação dos haplótipos A e B de $R$. sanguineus no estado de Mato Grosso do Sul e sua importância como vetor de vários patógenos de interesse veterinário. Finalmente, este é o primeiro relato de $C$. bainae em carrapatos na região centro-oeste do Brasil.

Palavras-chave: Carrapato, caracterização genética, cão, Centro-Oeste, Brasil.

\section{Introduction}

Ticks and tick-borne pathogens constitute an important problem of medical and veterinary concern around the world. Several microorganisms (e.g., Rickettsia rickettsii, Borrelia burgdorferi and Ehrlichia canis) transmitted by ticks may cause infection in humans and animals (Almeida et al., 2013; Schreiber et al., 2014). Therefore, studies on the detection of ticks and their associated pathogens provide valuable information to better understand their epidemiology (Schreiber et al., 2014).

Among the tick species infesting dogs, Rhipicephalus sanguineus sensu lato is considered the most important and is widespread throughout the world. Two genetic lineages are currently recognized within this species (i.e., the Southern or temperate lineage and the Northern or tropical lineage) (Moraes-Filho et al., 2011). The vector competence of ticks belonging to these different lineages has been subject of speculation. For example, differences have been observed in the transmission of distinct Brazilian strains of $E$. canis to dogs (Moraes-Filho et al., 2015) and it is likely that this variation in vector competence also holds true for other pathogens. In the state of Mato Grosso do Sul (central western Brazil), little is known about the occurrence of different lineages of $R$. sanguineus, although there is evidence of genetic similarity between local strains and those recognized as tropical lineages and reported in the States of Rio de Janeiro and São Paulo (Burlini et al., 2010; Moraes-Filho et al., 2011).

Ehrlichia canis and Anaplasma platys are among the most prevalent and diseasecausing pathogens in dogs in Brazil (Ramos et al., 2010; Soares et al., 2017). On the other hand, the distribution and epidemiological impact of other pathogens are poorly documented. For instance, although the filarid Cercopithifilaria bainae was first reported in Brazil in 1984 (Almeida \& Vicente, 1984), the parasite has only gained attention in the last four years, especially in the North-Eastern regions of the country (Ramos et al., 2016; Santos et al., 2017).

Researchers have placed increasing importance on investigating the occurrence of pathogens in ticks (Schreiber et al., 2014; Melo et al., 2016), which is an interesting alternative to surveys carried out in dogs, especially for pathogens that present with low parasitemia. Therefore, the present study aimed to characterize $R$. sanguineus strains infesting dogs in Campo Grande, State of Mato Grosso do Sul, Brazil, as well as to identify the main pathogens carried by this tick.

\section{Materials and Methods}

The present study was approved by the Ethics Committee for Animal Experimentation of the Federal University of Mato Grosso do Sul (protocol number: 961/2018).

Ticks were collected from 73 naturally infested domiciled dogs at the Veterinary Teaching Hospital of the Federal University of Mato Grosso do Sul and the Zoonosis Control Center, municipality of Campo Grande (20³0'32.0"S 54³7'15.2"W), Mato Grosso do Sul (MS), Brazil.

Ticks were manually and randomly collected from each dog during a period of $5 \mathrm{~min}$, for a total of 432 ticks. The specimens were placed in glass vials containing $70 \%$ ethanol 
and subsequently identified based on morphological characteristics, according to BarrosBattesti et al. (2006).

Adult ticks were pooled (three to five per animal) and DNA was extracted from them. The ticks were first washed with autoclaved distilled water and dried. The selected parasites were macerated in microtubes; this was followed by addition of $500 \mu \mathrm{l}$ of $20 \%$ sodium dodecyl sulfate and $10 \mu \mathrm{l}$ of proteinase $\mathrm{K}(20 \mathrm{mg} / \mathrm{ml})$, incubation for 24 hours at $56^{\circ} \mathrm{C}$, addition of $400 \mu \mathrm{l}$ of chloroform and vigorous homogenization by vortexing. After the addition of $300 \mu \mathrm{l}$ of protein precipitation solution $(0.8 \mathrm{M}$ potassium acetate and $11 \%$ glacial acetic acid), the mixture was centrifuged at $10,000 \times \mathrm{g}$ for 10 minutes. The aqueous phase was transferred to a microtube and DNA was precipitated by the addition of $1 \mathrm{ml}$ of $100 \%$ ethanol. After centrifugation at $10,000 \times \mathrm{g}$ for 5 minutes, the pellet was washed with $1 \mathrm{ml}$ of $70 \%$ ethanol and dried at room temperature (approximately $25^{\circ} \mathrm{C}$ ) for 30 minutes. The pellet was suspended in $1 \times$ TE buffer. DNA integrity and quantity were evaluated by electrophoresis in $0.8 \%$ agarose gels and spectrophotometry (A260/A280), respectively.

Samples were submitted to polymerase chain reaction (PCR) using the primers described in Table 1. A single PCR was used for the detection of Cercopithifilaria sp., B. vogeli, Hepatozoon sp., and Rickettsia sp., and a nested PCR was used for E. canis and A. platys. The PCR products were visualized in an UV transilluminator after $1.5 \%$ agarose gel electrophoresis and staining with Gel Red (Biotium, Fremont, CA, USA).

Table 1. Polymerase chain reaction primers used to test DNA extracts of ticks sampled from dogs in Campo Grande, Mato Grosso do Sul, Brazil.

\begin{tabular}{|c|c|c|c|c|}
\hline $\begin{array}{c}\text { Target } \\
\text { organism }\end{array}$ & Primers (5'-3') & Gene & $\begin{array}{l}\text { Amplicon } \\
\text { (bp) }\end{array}$ & Reference \\
\hline Ticks & $\begin{array}{l}\text { 16S Tick F- CCGGTCTGAACTCAGATCAAGT } \\
\text { 16S Tick R- GCTCAATGATIIITAAATTGCTGT }\end{array}$ & 16S rRNA & 460 & $\begin{array}{l}\text { Mangold et al. } \\
\qquad(1998)\end{array}$ \\
\hline Babesia vogeli & $\begin{array}{l}\text { Bab1- TGAACCTTATCACTTAAAGG } \\
\text { Bab4- CAACTCCTCCACGCAATCG }\end{array}$ & 18S rRNA & 590 & $\begin{array}{l}\text { Duarte et al. } \\
\qquad(2008)\end{array}$ \\
\hline Hepatozoon sp. & $\begin{array}{l}\text { HepF- ATACATGAGCAAAATCTCAAC } \\
\text { HepR- CTTATTATTCCATGCTGCAG }\end{array}$ & 18S rRNA & 666 & $\begin{array}{l}\text { Inokuma et al. } \\
\qquad(2002)\end{array}$ \\
\hline Ehrlichia canis & $\begin{array}{l}\text { ECC - AGAACGAACGCTGGCGGCAAGCC } \\
\text { ECB - CGTATTACCGCGGCTGCTGGC } \\
\text { HE- ATAGGTACCGTCATTATCTTCCCTAT* } \\
\text { ECA-CAATTATTATAGCCTCTGGCTATAGGAA* }\end{array}$ & 16S rRNA & 389 & $\begin{array}{l}\text { Wen et al. } \\
\text { (1997) }\end{array}$ \\
\hline $\begin{array}{l}\text { Anaplasma } \\
\text { platys }\end{array}$ & $\begin{array}{l}\text { 8F- AGTTTGATCATGGCTCAG } \\
\text { 1448R- CCATGGCGTGACGGGCAGTGT } \\
\text { PLATYS- GATIITGTCGTAGCTTGCTATG* } \\
\text { EHR16SR- TAGCACTCATCGITACAGC* }\end{array}$ & 16S rRNA & 678 & $\begin{array}{l}\text { Martin et al. } \\
\qquad(2005)\end{array}$ \\
\hline $\begin{array}{l}\text { Cercopithifilaria } \\
\text { sp. }\end{array}$ & $\begin{array}{l}\text { Fila12SF- CGGGAGTAAAGTाTGTITAAACCG } \\
\text { Fila12SR- CATTGACGGATGGTITGTACCAC }\end{array}$ & $12 \mathrm{~S}$ rRNA & 330 & $\begin{array}{l}\text { Otranto et al. } \\
\qquad(2011)\end{array}$ \\
\hline Rickettsia spp. & $\begin{array}{l}\text { CS78- GCAAGTATCGGTGAGGATGTAAT } \\
\text { Cs323- GCTTCCTTAAAATTCAATAAATCAGGAT }\end{array}$ & $g / t A$ & 401 & $\begin{array}{l}\text { Labruna et al. } \\
\text { (2004) }\end{array}$ \\
\hline
\end{tabular}

*Used in a nested-PCR reaction. 
Amplicons were purified using Clean Sweep PCR Purification reagent (Thermo Fisher Scientific Carlsbad, CA, USA) and sequenced in both directions by Sanger sequencing in an ABI-3130 automated sequencer (Applied Biosystems). Sequences were analyzed with the aid of Contig editor version 2.2.0 (Gene Studio Inc), and the identity of DNA sequences was determined by comparison with sequences available in the GenBank database using the BLASTn search tool.

Ten tick-positive samples were subjected to $16 \mathrm{~S}$ rRNA sequencing. A phylogenetic tree was constructed using the UPGMA method (Sneath \& Sokal, 1973). DNA sequences of ticks available in the GenBank database were used for phylogenetic analysis. Bootstrap resampling (1000 replicates) was performed for statistical support of reliability of tree nodes (Felsenstein, 1985) using the MEGA software version 6.0 (Tamura et al., 2013).

Moreover, five samples positive for Cercopithifilaria sp., four positive for E. canis, four positive for A. platys, and two positive for Hepatozoon sp., were similarly submitted for DNA sequencing. The DNA sequences were deposited in Genbank under the accession numbers shown in Table 2.

Table 2. Genbank accession numbers for the DNA sequences amplified from ticks sampled from dogs in Campo Grande, Mato Grosso do Sul, Brazil.

\section{Sequence identification}

\begin{tabular}{ll}
\hline Rhipicephalus sanguineus Campo Grande/MS 10 & MG793426 \\
\hline Rhipicephalus sanguineus Campo Grande/MS 12 & MG793427 \\
\hline Rhipicephalus sanguineus Campo Grande/MS 15 & MG793428 \\
\hline Rhipicephalus sanguineus Campo Grande/MS 18 & MG793429 \\
\hline Rhipicephalus sanguineus Campo Grande/MS 20 & MG793430 \\
\hline Rhipicephalus sanguineus Campo Grande/MS 22 & MG793431 \\
\hline Rhipicephalus sanguineus Campo Grande/MS 24 & MG793432 \\
\hline Rhipicephalus sanguineus Campo Grande/MS 25 & MG793433 \\
\hline Rhipicephalus sanguineus Campo Grande/MS 30 & MG793434 \\
\hline Rhipicephalus sanguineus Campo Grande/MS 38 & MG793435 \\
\hline Cercopithifilaria bainae Campo Grande/MS 01 & MG793436 \\
\hline Cercopithifilaria bainae Campo Grande/MS 02 & MG793437 \\
\hline Cercopithifilaria bainae Campo Grande/MS 03 & MG793438 \\
\hline Cercopithifilaria bainae Campo Grande/MS 04 & MG793439 \\
\hline Cercopithifilaria bainae Campo Grande/MS 05 & MG793440 \\
\hline Ehrlichia canis Campo Grande/MS 01 & MG793441 \\
\hline Ehrlichia canis Campo Grande/MS 02 & MG793442 \\
\hline Ehrlichia canis Campo Grande/MS 03 & MG793443 \\
\hline Ehrlichia canis Campo Grande/MS 04 & MG793444 \\
\hline Anaplasma platys Campo Grande/MS 01 & MG793445 \\
\hline Anaplasma platys Campo Grande/MS 02 & MG793446 \\
\hline Anaplasma platys Campo Grande/MS 03 & MG793447 \\
\hline Hepatozoon canis Campo Grande/MS 01 & MG793448 \\
\hline
\end{tabular}

\section{Results and Discussion}

All ticks analyzed in the present study were morphologically identified as $R$. sanguineus partially or completely engorged ( $n=432$, including 8 larvae, 59 nymphs and 365 adults). The $16 \mathrm{~S}$ rRNA gene was amplified from all 73 samples (pools); the 10 samples sequenced revealed $\geq 99 \%$ identity (100\% coverage) with sequences of $R$. sanguineus available in the Genbank database. 
In the phylogenetic analysis, the Campo Grande (CG) strains clustered with haplotypes A and B (Figure 1), previously identified by Moraes-Filho et al. (2011) and defined as tropical haplotypes.

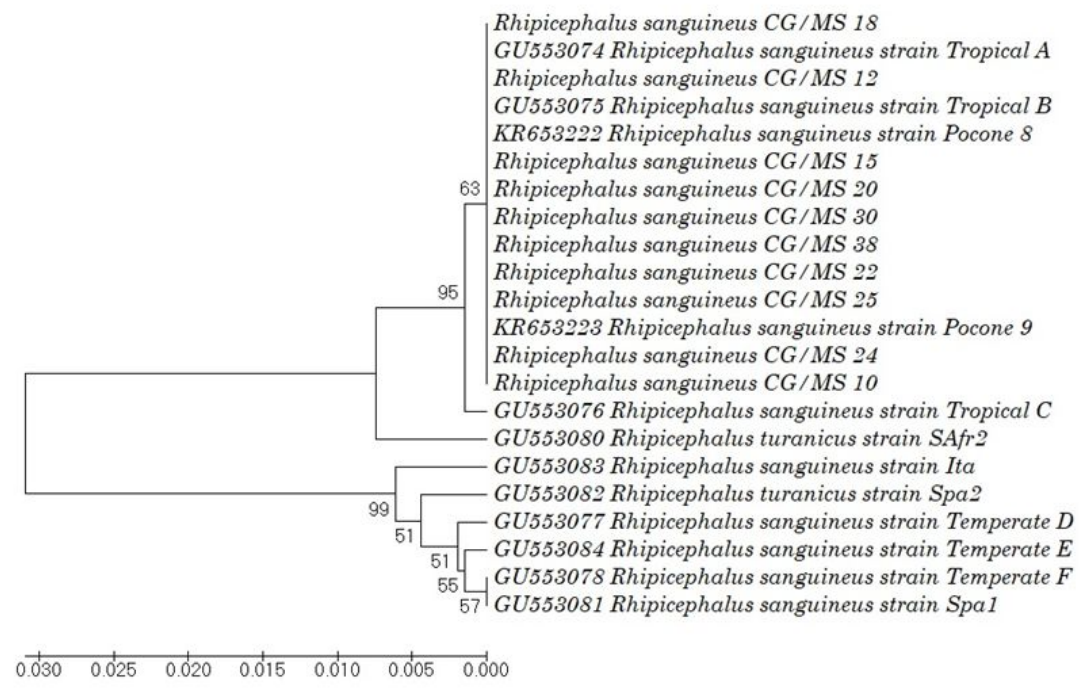

Figure 1. Phylogenetic tree constructed with the UPGMA method showing the relationship between strains of Rhipicephalus sanguineus from Campo Grande, MS, Brazil, and other isolates available in Genbank.

The present results confirmed the presence of these $R$. sanguineus haplotypes in the region and corroborate the observations made by Melo et al. (2016), who found only the $\mathrm{A}$ and $\mathrm{B}$ haplotypes in the Pantanal region of the state of Mato Grosso, Brazil. The C haplotype described in the Northern regions of South America (e.g., Colombia) (Moraes-Filho et al., 2011) segregated into a separate branch from the strains from Mato Grosso do Sul, but with all these haplotypes having a common ancestry. In contrast, the D, E, and F haplotypes (temperate haplotypes) formed a separate clade, supported by a high bootstrap value. These haplotypes have been reported in Chile, Argentina, Uruguay, and Southern Brazil (state of Rio Grande do Sul) (Moraes-Filho et al., 2011) and have greater genetic proximity to strains from Europe (Szabó et al., 2005).

Regarding the pathogens analyzed from ticks (divided in 73 pools) by PCR, Cercopithifilaria sp., (43.83\%; 32/73), E. canis (24.65\%; 18/73), A. platys (19.17\%; 14/73), and Hepatozoon sp. $(5.47 \% ; 4 / 73)$ were identified. DNA from Babesia vogeli and Rickettsia spp. was not detected in any sample. The DNA sequencing results confirmed the presence of C. bainae, E. canis, A. platys, and H. canis in ticks from Campo Grande, and the sequences were deposited in Genbank under the accession numbers shown in Table 2.

A part from C. bainae, all other pathogens have been frequently reported in dogs in the region of interest (Ramos et al., 2015; Soares et al., 2017), among which E. canis stands out as the most prevalent agent and is often associated with veterinary health problems. An E. canis infection rate of $55.75 \%$ of has been described in pet dogs from Campo Grande- MS (Soares et al., 2017), as well as a rate of $8.5 \%$ in stray cats in the same region (André et al., 2015).

The high prevalence of $E$. canis in dogs in the region may also be associated with the presence of $\mathrm{A}$ and $\mathrm{B}$ haplotypes of $R$. sanguineus observed in the present study, corroborating the findings of a vector competence study by Moraes-Filho et al. (2015), who observed in that the tropical haplotype of $R$. sanguineus is more effective at transmitting $E$. canis to dogs compared to temperate haplotypes. 
It should be highlighted that $A$. platys was one of the most frequent pathogens found in the studied ticks (19.17\%), a finding which is compatible with the A. platys prevalence rate described in dogs in the region. According to Soares et al. (2017), the infection frequency of dogs by A. platys in Campo Grande was 16.96\% between 2007 and 2009. The high prevalence of $A$. platys and $E$. canis in dogs and ticks in the region provides evidence that the $\mathrm{A}$ and $\mathrm{B}$ haplotypes of $R$. sanguineus are competent vectors for both pathogens, which can be found in the same geographic areas where the tropical haplotypes ( $\mathrm{A}$ and $\mathrm{B}$ ) of $R$. sanguineus circulate.

Another important result of the present study was the identification, for the first time, of $C$. bainae in ticks from the central western region of Brazil. Rhipicephalus sanguineus is a vector for this filarid, which parasitizes the dermis of dogs (Brianti et al., 2012). It has been recently described in dogs and $R$. sanguineus in North-Eastern Brazil (Ramos et al., 2016; Santos et al., 2017). However, its clinical importance remains unknown. In the present study, $R$. sanguineus (haplotypes $\mathrm{A}$ and $\mathrm{B}$ ) was considered a competent vector for this pathogen in the region, since C. bainae was detected in $43.83 \%$ of tick samples. Despite the small number of collected ticks and the analyses being carried out in pools, this prevalence was very high, since Santos et al. (2017) found C. bainae in only 51 (2.67\%) out of 1906 ticks.

Moreover, Otranto et al. (2012) found the frequency of ticks positive for C. bainae (determined through molecular analysis) to be lower than 3.9\% in the studied regions of Italy, Spain, and Greece, although the frequencies of infection in dogs in these regions ranged from 0 to $45.4 \%$. This indicates that the frequency of dogs infected by C. bainae in the city of Campo Grande may be high as well. Further studies are needed to clarify this issue.

In the present study, Hepatozoon canis was detected in only $5.47 \%(4 / 73)$ of the $R$. sanguineus samples, but this prevalence is compatible with this pathogen infecting dogs $(3.63 \%$; 6/165) from the same region (Ramos et al., 2015). Although $R$. sanguineus has been implicated as the main vector of $H$. canis pathogens in urban areas of Brazil, low infection rates have been reported in dogs, despite high tick infestation rates (Ramos et al., 2010; Ramos et al., 2015). The prevalence observed in dogs and ticks from Campo Grande- MS points to the low competence of $R$. sanguineus ( $\mathrm{A}$ and $\mathrm{B}$ haplotypes) in acquiring and transmitting these specific isolates of the protozoan.

Previous studies have reported unsuccessful attempts at describing the development of $H$. canis in ticks, including $R$. sanguineus from Brazil (Forlano et al., 2005; Gomes et al., 2010; Demoner et al., 2013). On the other hand, the development of $H$. canis in populations of $R$. sanguineus in Europe has been reported frequently (Baneth et al., 2001; Giannelli et al., 2013). Therefore, genetic and morphological variability in $R$. sanguineus populations can probably be attributed to the tick's ability to transmit this pathogen in different regions.

Although no DNA from Babesia vogeli and Rickettsia spp. was found in the tick pools analyzed, both pathogens occur in the region, albeit at a low frequency. DNA from Babesia vogeli was found in dogs from the city of Campo Grande at a frequency of only $3.3 \%$ (2/60) (Sousa et al., 2013). Rickettsia rickettsii was identified in only one tick of a total of 2015 specimens collected from dogs in the city of Campo Grande (Almeida et al., 2013).

The results of the present study confirm the presence of C. bainae, E. canis, A. platys, and $H$. canis in dogs in the municipality of Campo Grande, MS, Brazil and demonstrate the importance of the tick $R$. sanguineus (haplotypes $\mathrm{A}$ and $\mathrm{B}$ ) as a host and potential vector of a set of pathogens in the region.

\section{Acknowledgements}

This work was supported by the Coordination of Improvement of Higher Education Personnel (CAPES), Brazil (Financing Code 001). 


\section{References}

Almeida GLG, Vicente JJ. Cercopithifilaria bainae sp. n. parasita de Canis familiaris (L.) (Nematoda, Filarioidea). Atas Soc Biol Rio de 1984; 24: 18.

Almeida RCF, Garcia MV, Cunha RC, Matias J, Silva EA, Matos MFC, et al. Ixodid fauna and zoonotic agents in ticks from dogs: first report of Rickettsia rickettsii in Rhipicephalus sanguineus in the state of Mato Grosso do Sul, mid-western Brazil. Exp Appl Acarol 2013; 60(1): 63-72. http://dx.doi.org/10.1007/s10493-012-9641-y. PMid:23229491.

Andre MR, Herrera HM, Fernandes SJ, Sousa KC, Goncalves LR, Domingos IH, et al. Tick-borne agents in domesticated and stray cats from the city of Campo Grande, state of Mato Grosso do Sul, midwestern Brazil. Ticks Tick Borne Dis 2015; 6(6): 779-786. http://dx.doi.org/10.1016/j.ttbdis.2015.07.004. PMid:26187416.

Baneth G, Samish M, Alekseev E, Aroch I, Shkap V. Transmission of Hepatozoon canis to dogs by naturally-fed or percutaneously-injected ticks Rhipicephalus sanguineus ticks. J Parasitol 2001; 87(3): 606-611. http://dx.doi.org/10.1645/0022-3395(2001)087[0606:TOHCTD]2.0.CO;2. PMid:11426725.

Barros-Battesti DM, Arzua M, Bechara GH. Carrapatos de importância médico-veterinária da região neotropical: um guia ilustrado para identificação de espécies. 1a ed. São Paulo: Vox/ICTTD3/Butantan; 2006.

Brianti E, Otranto D, Dantas-Torres F, Weigl S, Latrofa MS, Gaglio G, et al. Rhipicephalus sanguineus (Ixodida, Ixodidae) as intermediate host of a canine neglected filarial species with dermal microfilariae. Vet Parasitol 2012; 183(3-4): 330-337. http://dx.doi.org/10.1016/j.vetpar.2011.07.031. PMid:21831524.

Burlini L, Teixeira KR, Szabó MP, Famadas KM. Molecular dissimilarities of Rhipicephalus sanguineus (Acari: Ixodidae) in Brazil and its relation with samples throughout the world: is there a geographical pattern? Exp Appl Acarol 2010; 50(4): 361-374. http://dx.doi.org/10.1007/s10493009-9321-8. PMid:19774468.

Demoner LC, Rubini AS, Paduan KS, Metzger B, Paula Antunes JM, Martins TF, et al. Investigation of tick vectors of Hepatozoon canis in Brazil. Ticks Tick Borne Dis 2013; 4(6): 542-546. http://dx.doi.org/10.1016/j.ttbdis.2013.07.006. PMid:24209494.

Duarte SC, Linhares GFC, Romanowsky TN, Silveira Neto OJ, Borges LMF. Assessment of primers designed for the subspecies-specific discrimination among Babesia canis canis, Babesia canis vogeli and Babesia canis rossi by PCR assay. Vet Parasitol 2008; 152(1-2): 16-20. http://dx.doi.org/10.1016/j.vetpar.2007.12.013. PMid:18242863.

Felsenstein J. Confidence limits on phylogenies: An approach using the bootstrap. Evolution 1985; 39(4): 783-791. http://dx.doi.org/10.1111/j.1558-5646.1985.tb00420.x. PMid:28561359.

Forlano M, Scofield A, Elisei C, Fernandes KR, Ewing SA, Massard CL. Diagnosis of Hepatozoon spp. in Amblyomma ovale and its experimental transmission in domestic dogs in Brazil. Vet Parasitol 2005; 134(1-2): 1-7. http://dx.doi.org/10.1016/j.vetpar.2005.05.066. PMid:16081219.

Giannelli A, Ramos RAN, Di Paola G, Mencke N, Dantas-Torres F, Baneth G, et al. Transstadial transmission of Hepatozoon canis from larvae to nymphs of Rhipicephalus sanguineus. Vet Parasitol 2013; 196(1-2): 1-5. http://dx.doi.org/10.1016/j.vetpar.2013.02.017. PMid:23537949.

Gomes PV, Mundim MJ, Mundim AV, Ávila DF, Guimarães EC, Cury MC. Occurrence of Hepatozoon sp. in dogs in the urban area originating from a municipality in southeastern Brazil. Vet Parasitol 2010; 174(1-2): 155-161. http://dx.doi.org/10.1016/j.vetpar.2010.07.020. PMid:20810218.

Inokuma H, Okuda M, Ohno K, Shimoda K, Onishi T. Analysis of the 18S rRNA gene sequence of a Hepatozoon detected in two Japanese dogs. Vet Parasitol 2002; 106(3): 265-271. http://dx.doi.org/10.1016/S0304-4017(02)00065-1. PMid:12062514.

Labruna MB, Whitworth T, Horta MC, Bouyer DH, McBride JW, Pinter A, et al. Rickettsia species infecting Amblyomma cooperi ticks from an area in the state of São Paulo, Brazil, where Brazilian spotted fever is endemic. J Clin Microbio/ 2004; 42(1): 90-98. http://dx.doi.org/10.1128/JCM.42.1.90-98.2004. PMid:14715737.

Mangold AJ, Bargues MD, Mas-Coma S. Mitochondrial 16S rDNA sequences and phylogenetic relationships of species of Rhipicephalus and other tick genera among Metastriata (Acari: 
ixodidae). Parasitol Res 1998; 84(6): 478-484. http://dx.doi.org/10.1007/s004360050433. PMid:9660138.

Martin AR, Brown GK, Dunstan RH, Roberts TK. Anaplasma platys: an improved PCR for its detection in dogs. Exp Parasitol 2005; 109(3): 176-180. http://dx.doi.org/10.1016/j.exppara.2004.11.007. PMid:15713449.

Melo ALT, Witter R, Martins TF, Pacheco TA, Alves AS, Chitarra CS, et al. A survey of tick-borne pathogens in dogs and their ticks in the Pantanal biome, Brazil. Med Vet Entomol 2016; 30(1): 112-116. http://dx.doi.org/10.1111/mve.12139. PMid:26467462.

Moraes-Filho J, Krawczak FS, Costa FB, Soares JF, Labruna MB. Comparative evaluation of the vector competence of four South american populations of the Rhipicephalus sanguineus group for the bacterium Ehrlichia canis, the agent of canine monocytic ehrlichiosis. PLoS One 2015; 10(9): e0139386. http://dx.doi.org/10.1371/journal.pone.0139386. PMid:26414283.

Moraes-Filho J, Marcili A, Nieri-Bastos FA, Richtzenhain LJ, Labruna MB. Genetic analysis of ticks belonging to the Rhipicephalus sanguineus group in Latin America. Acta Trop 2011; 117(1): 51-55. http://dx.doi.org/10.1016/j.actatropica.2010.09.006. PMid:20858451.

Otranto D, Brianti E, Abramo F, Gaglio G, Napoli E, Latrofa MS, et al. Cutaneous distribution and localization of Cercopithifilaria sp. microfilariae in dogs. Vet Parasitol 2012; $190(1-2)$ : 143-150. http://dx.doi.org/10.1016/j.vetpar.2012.05.016. PMid:22698796.

Otranto D, Brianti E, Dantas-Torres F, Weigl S, Latrofa MS, Gaglio G, et al. Morphological and molecular data on the dermal microfilariae of a species of Cercopithifilaria from a dog in Sicily. Vet Parasito/ 2011; 182(2-4): 221-229. http://dx.doi.org/10.1016/j.vetpar.2011.05.043. PMid:21705146.

Ramos CA, Babo-Terra VJ, Pedroso TC, Souza Filho AF, Araújo FR, Cleveland HP. Molecular identification of Hepatozoon canis in dogs from Campo Grande, Mato Grosso do Sul, Brazil. Rev Bras Parasito/ Vet 2015; 24(2): 247-250. http://dx.doi.org/10.1590/S1984-29612015019. PMid:26154969.

Ramos RA, Oliveira RAG, Farias FED, Ramos CA, Carvalho GA, Dantas-Torres F, et al. Filarioids infecting dogs in northeastern Brazil. Vet Parasitol 2016; 226: 26-29. http://dx.doi.org/10.1016/j.vetpar.2016.06.025. PMid:27514878.

Ramos RAN, Ramos CAN, Araújo FR, Oliveira R, Souza I, Pimentel D, et al. Molecular survey and genetic characterization of tick-borne pathogens in dogs in metropolitan Recife (north-eastern Brazil). Parasitol Res 2010; 107(5): 1115-1120. http://dx.doi.org/10.1007/s00436-010-1979-7. PMid:20680344.

Santos MAB, Souza IB, Macedo LO, Nascimento Ramos CA, Oliveira Rego AG, Alves LC, et al. Cercopithifilaria bainae in Rhipicephalus sanguineus sensu lato ticks from dogs in Brazil. Ticks Tick Borne Dis 2017; 8(4): 623-625. http://dx.doi.org/10.1016/j.ttbdis.2017.04.007. PMid:28442240.

Schreiber C, Krucken J, Beck S, Maaz D, Pachnicke S, Krieger K, et al. Pathogens in ticks collected from dogs in Berlin/Brandenburg, Germany. Parasit Vectors 2014; 7(1): 535. http://dx.doi.org/10.1186/s13071-014-0535-1. PMid:25441762.

Sneath PHA, Sokal RR. Numerical Taxonomy. Freeman: San Francisco; 1973.

Soares R, Ramos CA, Pedroso T, Babo-Terra VJ, Cleveland HPK, Araújo FR. Molecular survey of Anaplasma platys and Ehrlichia canis in dogs from Campo Grande, Mato Grosso do Sul, Brazil. An Acad Bras Cienc 2017; 89(1): 301-306. http://dx.doi.org/10.1590/0001-3765201720150556. PMid:28423085.

Sousa KC, André MR, Herrera HM, Andrade GB, Jusi MM, dos Santos LL, et al. Molecular and serological detection of tick-borne pathogens in dogs from an area endemic for Leishmania infantum in Mato Grosso do Sul, Brazil. Rev Bras Parasitol Vet 2013; 22(4): 525-531. http://dx.doi.org/10.1590/S1984-29612013000400012. PMid:24473877.

Szabó MP, Mangold AJ, João CF, Bechara GH, Guglielmone AA. Biological and DNA evidence of two dissimilar populations of the Rhipicephalus sanguineus tick group (Acari: Ixodidae) in South America. Vet Parasito/ 2005; 130(1-2): 131-140. http://dx.doi.org/10.1016/j.vetpar.2005.03.008. PMid:15893080. 
Tamura K, Stecher G, Peterson D, Filipski A, Kumar S. MEGA6: Molecular Evolutionary Genetics Analysis version 6.0. Mol Biol Evol 2013; 30(12): 2725-2729. http://dx.doi.org/10.1093/molbev/mst197. PMid:24132122.

Wen B, Rikihisa Y, Mott JM, Greene R, Kim HY, Zhi N, et al. Comparison of nested PCR with immunofluorescent-antibody assay for detection of Ehrlichia canis infection in dogs treated with doxycycline. J Clin Microbiol 1997; 35(7): 1852-1855. PMid:9196207. 